\title{
Transcriptional and Posttranslational Regulation of Nucleotide Excision Repair: The Guardian of the Genome against Ultraviolet Radiation
}

\author{
Jeong-Min Park and Tae-Hong Kang * \\ Department of Biological Science, Dong-A University, Busan 49315, Korea; zmpark@donga.ac.kr \\ * Correspondence: thkang@dau.ac.kr; Tel.: +82-51-200-7261; Fax: +82-51-200-7269
}

Academic Editor: Terrence Piva

Received: 20 September 2016; Accepted: 1 November 2016; Published: 4 November 2016

\begin{abstract}
Ultraviolet (UV) radiation from sunlight represents a constant threat to genome stability by generating modified DNA bases such as cyclobutane pyrimidine dimers (CPD) and pyrimidine-pyrimidone (6-4) photoproducts (6-4PP). If unrepaired, these lesions can have deleterious effects, including skin cancer. Mammalian cells are able to neutralize UV-induced photolesions through nucleotide excision repair (NER). The NER pathway has multiple components including seven xeroderma pigmentosum (XP) proteins (XPA to XPG) and numerous auxiliary factors, including ataxia telangiectasia and Rad3-related (ATR) protein kinase and RCC1 like domain (RLD) and homologous to the E6-AP carboxyl terminus (HECT) domain containing E3 ubiquitin protein ligase 2 (HERC2). In this review we highlight recent data on the transcriptional and posttranslational regulation of NER activity.
\end{abstract}

Keywords: ultraviolet radiation; nucleotide excision repair; transcriptional regulation; posttranslational regulation

\section{Introduction}

Ultraviolet (UV) radiation from sunlight continuously damages an organism's genome. The solar UV spectrum can be divided into UVA (315-400 nm), UVB (280-315 nm), and UVC $(100-280 \mathrm{~nm})$ radiation [1,2]. Short-wavelength UVC (especially $254 \mathrm{~nm}$ ) and medium-wavelength UVB readily produce DNA photoproducts such as cyclobutane pyrimidine dimers (CPD) and pyrimidine-pyrimidone (6-4) photoproducts (6-4PP) [3,4]. Because these photolesions interfere with DNA replication and transcription, they can lead to cell death and mutagenesis, thereby threatening genome stability [5]. Furthermore, these lesions can induce UV signature mutations ( $\mathrm{C} \rightarrow \mathrm{T}$ transition and $\mathrm{CC} \rightarrow$ TT tandem double mutations), which are the main cause of photocarcinogenesis $[6,7]$.

Nucleotide excision repair (NER) is the only DNA repair system able to remove UV-induced photolesions in placental mammals [8,9]. NER also can repair other bulky DNA adducts, reactive oxygen species-induced base modifications, and intrastrand crosslinks [10]. The two distinct damage recognition subpathways that comprise NER are global genome NER (GG-NER) and transcription-coupled repair (TC-NER). The GG-NER subpathway is activated by the DNA damage sensor protein xeroderma pigmentosum complementation group C (XPC), whereas the TC-NER subpathway is activated by the stalling of RNA polymerase II (RNAPII) during transcription [11]. Hereditary mutations in NER-associated genes are associated with disorders that are characterized by UV sensitivity and cancer predisposition, such as xeroderma pigmentosum, Cockayne syndrome, and trichothiodystrophy $[12,13]$. Therefore, an understanding of the precise mechanisms underlying NER is needed to develop clinical interventions to counteract skin aging and cancer. In this review 
we highlight recent findings on the regulation of NER activity at the transcriptional and posttranslational levels (Figure 1).

Transcriptional regulation
Posttranslational regulation
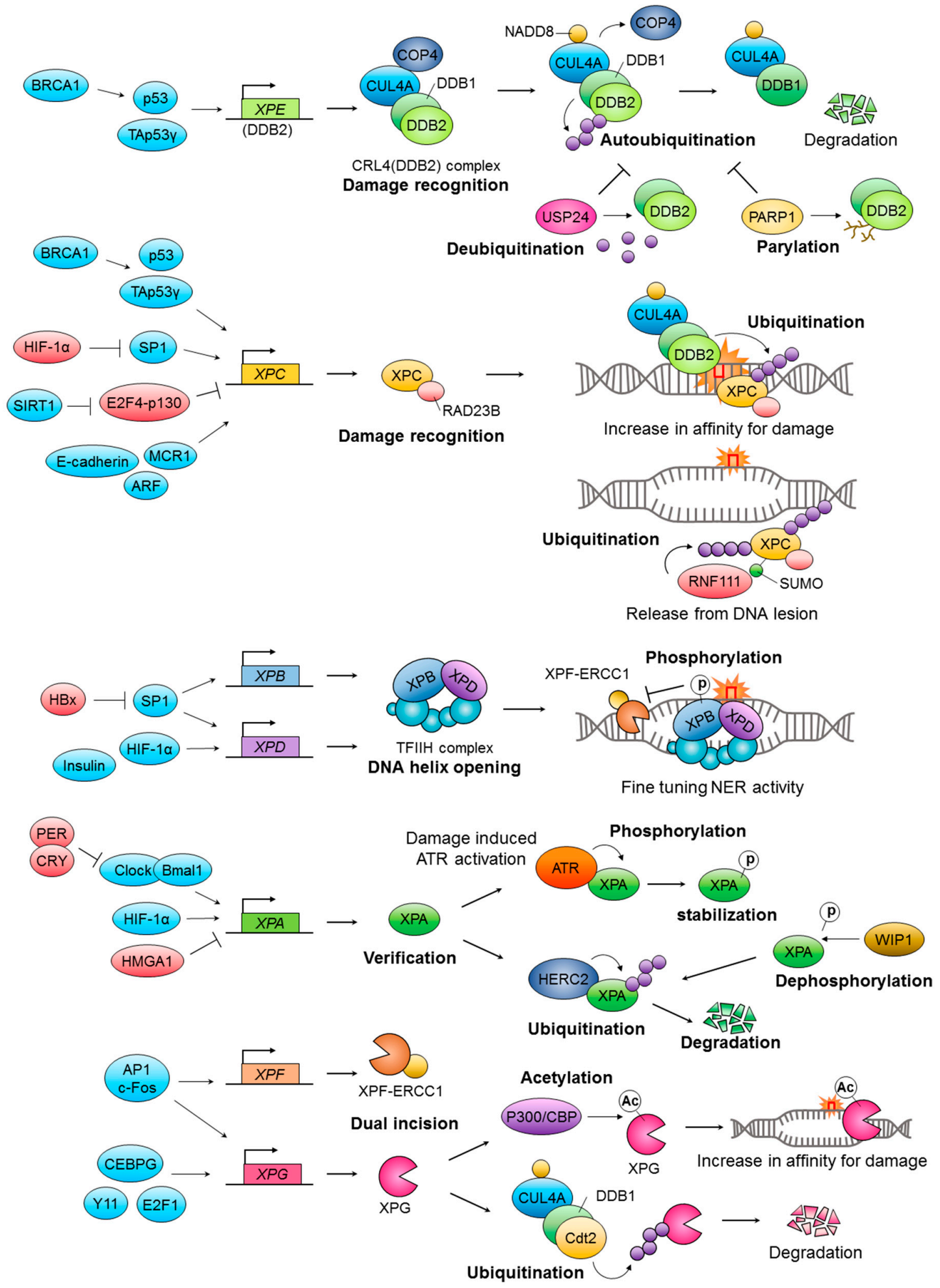

Figure 1. Schematic illustration for transcriptional and posttranslational modifications of core nucleotide excision repair (NER) factors. See text for detailed description. 


\section{Transcriptional Regulation of Nucleotide Excision Repair (NER)}

\section{Transcriptional Regulation of Core NER Factors}

Successful NER requires at least seven core NER factors (i.e., xeroderma pigmentosum (XP) proteins XPA-XPG) [14]. In Table 1, we summarized factors implicated in the transcriptional regulation of core NER factors.

Table 1. A summary of transcriptional regulation of core nucleotide excision repair (NER) factors.

\begin{tabular}{|c|c|c|c|c|}
\hline \multirow{2}{*}{$\mathbf{X} \mathbf{P}^{1}$} & \multirow{2}{*}{ Function in NER } & \multicolumn{3}{|c|}{ Transcriptional Regulation } \\
\hline & & Factor & Regulation & Reference \\
\hline \multirow[t]{3}{*}{$\mathrm{XPA}$} & Damage verification & Cry1 & Down & {$[15,16]$} \\
\hline & & HMGA1 & Down & {$[17]$} \\
\hline & & HIF- $1 \alpha$ & Up & [18] \\
\hline \multirow[t]{2}{*}{$\mathrm{XPB}$} & ATP-dependent helicase & Sp1 & $\mathrm{Up}$ & [19] \\
\hline & & HBx & Down & [20] \\
\hline \multirow[t]{10}{*}{$\mathrm{XPC}$} & Damage recognition & p53 & $\mathrm{Up}$ & {$[21,22]$} \\
\hline & & 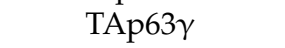 & Up & {$[23]$} \\
\hline & & BRCA1 & UP & [24] \\
\hline & & Sp1 & $\mathrm{Up}$ & {$[25,26]$} \\
\hline & & HIF-1 $\alpha$ & Down & {$[26]$} \\
\hline & & E2F4-p130 & Down & {$[27,28]$} \\
\hline & & SIRT1 & UP & [27] \\
\hline & & $\mathrm{ARF}$ & UP & [28] \\
\hline & & E-cadherin & Up & [29] \\
\hline & & MC1R & Up & [30] \\
\hline \multirow[t]{3}{*}{ XPD } & ATP-dependent helicase & HBx & Down & [20] \\
\hline & & HIF-1 $\alpha$ & $\mathrm{Up}$ & {$[26]$} \\
\hline & & Insulin & $\mathrm{Up}$ & [31] \\
\hline \multirow[t]{3}{*}{$\mathrm{XPE}$} & Damage recognition & p53 & $\mathrm{Up}$ & {$[22,32]$} \\
\hline & & TAp63 $\gamma$ & $\mathrm{Up}$ & [23] \\
\hline & & BRCA1 & Up & [24] \\
\hline $\mathrm{XPF}$ & $5^{\prime}$ incision endonuclease & c-Fos, AP-1 & Up & {$[33,34]$} \\
\hline \multirow[t]{2}{*}{ XPG } & $3^{\prime}$ incision endonuclease & c-Fos, AP-1 & $\mathrm{Up}$ & [33] \\
\hline & & CEBPG, E2F1, YY1 & UP & [35] \\
\hline
\end{tabular}

${ }^{1} \mathrm{XP}$ : xeroderma pigmentosum.

The XPA protein is a rate-limiting factor for the entire NER process, and its expression level determines NER capacity [36]. XPA is required for damage verification in both GG-NER and TC-NER subpathways, triggering dual incision of the lesion by recruiting endonucleases XPF and XPG [37,38]. The transcription of XPA is controlled by a molecular circadian clock composed of a Clock-Bmal1 transcriptional activator and Cry-Per transcriptional repressor [39]. The daily oscillation of circadian clock activity results in the rhythmic expression of XPA in most differentiated mammalian tissues, including the brain and liver $[15,16]$. However, mice lacking clock activity due to the genetic knock-out of Cry show no rhythmic XPA transcription and thus no daily oscillation of NER activity in the mouse liver tissue [16]. Other factors regulating XPA expression include high mobility group protein A1 (HMGA1) and hypoxia-inducible factor-1 $\alpha$ (HIF-1 $\alpha)$. The overexpression of HMGA1 in MCF-7 breast cancer cells downregulates XPA transcription and thus increases UV sensitivity [17,40], whereas HIF-1 $\alpha$ binding to the hypoxia response element (HRE) in the XPA promoter upregulates XPA expression approximately five-fold, implying that targeting HIF-1 $\alpha$ may improve chemo-efficacy [18].

XPB (also known as excision repair cross-complementation group 3, ERCC3) and XPD (ERCC2) are components of the transcription factor IIH (TFIIH) complex. These proteins function as 
ATP-dependent DNA helicases, opening DNA strands around the site of damage [41]. Expression of XPB is regulated by specificity protein 1 (Sp1), which binds to the XPB promoter and activates transcription [19,42]. Hepatitis B virus $\mathrm{x}(\mathrm{HBx})$ protein can bind to and inhibit Sp1 activity, thereby downregulating the expression of XPB [20,43]. The expression of XPD is regulated by HIF-1 $\alpha$, which binds to seven overlapping HRE regions in the XPD promoter [26], and by the insulin-dependent signaling pathway [31]. A long-term exposure to high glucose concentrations $(>10 \mathrm{mM})$ induces a downregulation of the insulin-dependent increase in XPD mRNA levels, suggesting that glucose and insulin are important regulators of XPD transcription, and prolonged exposure to high levels of glucose may impair the insulin-dependent regulation of DNA repair.

The damage sensor XPC recognizes distortions in the DNA helix [44,45], and XPE (also known as DNA damage-binding protein 2 (DDB2)) recognizes and binds to UV-induced CPD, facilitating subsequent XPC binding [46]. After UV irradiation, the expression of XPC and XPE is increased in a p53-dependent manner. The XPC promoter contains a putative p53 response element that interacts with p53 in vitro [21]. Similarly, the XPE promoter contains a p53 binding site [32]. The p53-dependent upregulation of XPC and XPE expression in malignant melanoma correlates with enhanced NER activity and consequently with chemoresistance [22]. Transactivation isoform of p63 gamma (TAp63 $\gamma$ ) is a p53 homolog that transcriptionally regulates p53 target genes [47]. Overexpression of TAp63 $\gamma$ stimulates expression of XPC and XPE at both mRNA and protein levels, further enhancing NER activity upon UV damage [23]. Breast cancer 1 (BRCA1), a key factor in DNA double-strand break repair, can enhance expression of XPC and XPE independent of p53 [24]. Defects in the NER pathway in BRCA1-associated breast cancers may be causal in tumor development. In addition, Sp1 binds to the XPC promoter to increase its expression after UV irradiation [25]. The Sp1-binding sequence overlaps the HRE sequence in the XPC promoter; thus HIF- $1 \alpha$ competes with $\mathrm{Sp} 1$ at the same binding site. Under normal conditions, HIF-1 $\alpha$ can suppress Sp1 binding, but with exposure to UV radiation, downregulation of HIF-1 $\alpha$ enables Sp1 binding to the XPC promoter, thereby increasing XPC expression [26]. Sirtuin 1 (SIRT1) stimulates XPC expression by blocking the nuclear localization of the transcriptional repressor E2F4-p130 [27]. Akt activation as a result of SIRT1 inhibition is critical for the nuclear accumulation of the E2F4-p130 repressor complex. SIRT1 also can interact with $\mathrm{Rb}$ (retinoblastoma protein), as well as its family members p103 and p130, and to deacetylate $\mathrm{Rb}$. It is possible that SIRT1 also acts as a deacetylase for p130, and thus plays an important role in regulating the function of the E2F4-p130 repressor complex in XPC transcription. Alternatively, Akt may phosphorylate p130, and thus loss of SIRT1 may increase the acetylation of p130, thus increasing nuclear p130 levels [27]. Similarly, the alternative reading frame (ARF) tumor suppressor disrupts the interaction of the E2F4-p130 with the XPC promoter to increase XPC expression levels [28]. The cell adhesion molecule E-cadherin increases XPC expression by disrupting E2F4-p130 transcription repressor complexes. Conversely, loss of E-cadherin activates the transforming growth factor beta (TGF- $\beta$ ) pathway, which upregulates E2F4-p130 and decreases XPC expression and NER activity [29]. Activation of melanocortin 1 receptor (MC1R) is associated with stimulation of XPC expression as well as ataxia telangiectasia and Rad3-related (ATR)-mediated H2AX phosphorylation to protect skin cells from UV irradiation [30].

XPF (ERCC4) and XPG (ERCC5) are structure-specific endonucleases that facilitate dual incision of the damaged strand [48]. The mRNA levels of XPF and XPG decline after UV irradiation but are quickly restored by activation of the transcriptional activation of c-Fos/AP-1 [33], which binds to the AP-1 binding site in the XPF promoter to induce its expression, increasing NER activity [34]. Thus, in c-Fos deficient cells, both XPF and XPG mRNA production are significantly reduced, which leads to decline of XPF protein levels after UV irradiation. Even though the XPG mRNA level is also deceased, the XPG protein level is not changed after UV irradiation due to the intrinsic higher stability of the XPG protein [33]. The XPF protein is stabilized by ERCC1, suggesting that ERCC1 expression influences XPF levels [49]. Transcriptional activation of ERCC1 is stimulated by oncogenic H-Ras, which subsequently triggers AP-1 transcriptional activity [50]. AP-1 is also transcriptionally 
upregulated by glioma-associated oncogene homolog 1 (Gli1); thus inhibition of Gli1 by small hairpin RNA downregulates AP-1, thereby decreasing ERCC1 and XPF expression [51]. The expression of XPG is upregulated by CCAAT/enhancer-binding protein gamma (CEBPG), whose expression is modulated by E2F1 and YY1 (Yin Yang 1) [35]. CEBPG belongs to a member of the CEBP family of transcription factors. The CEBP family proteins form homodimers or heterodimers to regulate CCAAT/enhancer element-mediated transcription. In this regard CEBPG also can form heterodimers with other CEBP proteins to transcriptionally activate XPG transcription.

\section{Posttranslational Regulation of NER Factors}

\subsection{Ubiquitination and SUMOylation}

Posttranslational modification is a fundamental mechanism in the regulation of protein functions. Recent data show that the activity of NER factors is also under control of posttranslational modifications. In Table 2, we summarized factors involved in the posttranslational regulation NER factors. Ubiquitination-i.e., attachment of ubiquitin to lysine residues on substrates-is important for regulating NER activity [52]. In the initiation of GG-NER, ubiquitination of XPC is mediated by the cullin-RING ubiquitin ligase (CRL) complex, which consists of damage-specific DNA binding protein 1 (DDB1), DDB2, regulator of cullins 1 (ROC1), and the cullin 4A (CUL4A) scaffold [53]. CRL4(DDB2) is inactivated by constitutive photomorphogenesis 9 (COP9) signalosome deneddylation activity in quiescent cells [54]. When DNA damage is detected by DDB2, this complex is activated by neural precursor cell expressed developmentally downregulated protein 8 (NEDD8), an ubiquitin-like protein involved in protein neddylation $[55,56]$. CRL4(DDB2) can ubiquitinate histones, XPC, and DDB2 itself [57-60]. The degradation of DDB2 is induced by Lys48-linked auto-ubiquitination via the $26 \mathrm{~S}$ proteasome, and this degradation is prevented by the deubiquitinating enzyme ubiquitin-specific processing protease 24 (USP24) $[60,61]$. However, DDB2-mediated XPC ubiquitination does not result in XPC degradation, and the protein retains its DNA-binding activity [53,62]. The activity of p38 mitogen-activated protein kinase (MAPK) kinase is required for DDB2 ubiquitination and degradation and for the recruitment of XPC and TFIIH onto sites of UV damage [63]. DDB2 phosphorylation at serine moiety by 38 MAPK facilitates ubiquitination and degradation of DDB2, but the specific site of serine phosphorylation by $\mathrm{p} 38$ MAPK and whether this phosphorylation is indispensable for UV-induced DDB2 ubiquitination has not been confirmed yet. UV radiation resistance-associated gene (UVRAG) protein, which is also required for efficient XPC recruitment, promotes the assembly and activity of the CRL4(DDB2) complex [64]. During UV exposure, UVRAG localizes to photolesions and associates with DDB1 to promote the assembly and activity of the DDB2-DDB1-Cul4A-Roc1 ubiquitin ligase complex, leading to efficient XPC recruitment to the lesions. Disruption of UVRAG-DDB1 interaction attenuates ubiquitination and association of XPC with UV-induced photolesions.

XPC is additionally modified by RING finger protein 111/Arkadia (RNF111) by Lys63-linked poly-ubiquitination. This modification stimulates XPC release from the DNA lesion, which is essential for completion of NER [65]. RNF111 selectively ubiquitinates SUMOylated XPC [66,67]. The SUMOylation of lysine residues 81, 89, and 183 of XPC promotes NER [68], whereas SUMOylation of lysine 655 is required for UV-induced XPC degradation [69].

When RNAPII stalls at the site of DNA damage, Cockayne syndrome protein B (CSB) stably binds to RNAPII and recruits CSA [11]. CSA then forms a complex with CUL4, ROC1 and DDB1 that appears to regulate the ubiquitination of CSB [70]. The ubiquitin-binding domain of CSB appears to be crucial for efficient TC-NER [71]. The UV-sensitive syndrome A (UVSSA) protein recruits USP7 to the stalled RNAPII, which promotes the deubiquitination of CSB, thereby counteracting the CSA-dependent ubiquitination of CSB and stabilizing CSB by inhibiting its degradation [72]. CSB also undergoes SUMOylation after UV irradiation, which is critical for the recruitment of CSA [73]. Therefore, UVSSA and CSA, through different ubiquitin-mediated mechanisms, seem to have opposite roles in determining the fate of CSB. 
As noted previously, XPA protein levels exhibit circadian oscillation. The control of XPA is accomplished by circadian clock-mediated transcriptional regulation and homologous to the E6-AP carboxyl terminus (HECT) domain and RCC1-like domain-containing protein 2 (HERC2)-mediated posttranslational regulation [16]. The HERC2-mediated ubiquitination of XPA leads to its degradation, which contributes to the high amplitude of XPA circadian oscillation [36]. After UV-induced DNA damage occurs, XPA recruits XPF-ERCC1 and XPG endonucleases to remove the damaged DNA strand. ERCC1 can be deubiquitinated by USP45, which promotes XPF-ERCC1 recruitment to sites of DNA damage [74]. Upon UV exposure, USP45 interacts with ERCC1-XPF but the USP45 mutant (Asp25Ala, Glu26Ala) that is catalytically active but that cannot bind to ERCC1 failed to deubiquitinate ERCC1. The major role of ERCC1 deubiquitination by USP45 has been speculated to enable ERCC1-XPF to gain access to DNA damage sites. After XPG cleaves strands on the $3^{\prime}$ side of the lesion, XPG elimination from the DNA is important for subsequent DNA repair. XPG is degraded in response to both UV and cisplatin treatments, and CRL4(Cdt2)-mediated XPG degradation facilitates the recruitment of DNA polymerase $\delta$ and DNA repair synthesis [75].

Table 2. A summary of posttranslational modification of NER factors.

\begin{tabular}{|c|c|c|c|c|c|}
\hline $\mathbf{X P}$ & Modification & Factor & Residue & Effect & Ref. \\
\hline \multirow[t]{4}{*}{$\mathrm{XPA}$} & Phosphorylation & ATR & Ser196 & Stabilization & {$[76,77]$} \\
\hline & Dephosphorylation & WIP1 & Ser196 & Inactivation & [78] \\
\hline & Ubiquitination & HERC2 & - & Degradation & {$[16,36]$} \\
\hline & Deacetylation & SIRT1 & Lys63, Lys67 & Stabilization, Interaction with RPA32 & {$[79]$} \\
\hline XPB & Phosphorylation & - & Ser751 & $\begin{array}{c}\text { Inhibition of } 5^{\prime} \text { incision by } \\
\text { XPF/ERCC } 1\end{array}$ & {$[80]$} \\
\hline \multirow[t]{6}{*}{$\mathrm{XPC}$} & Ubiquitination & CRL4(DDB2) & - & Affinity for DNA lesions & {$[53,59]$} \\
\hline & Ubiquitination & RNF111 & - & Release from DNA lesions & [66] \\
\hline & SUMOylation & SUMO2 & - & RNF111 induced ubiquitination & {$[65,66]$} \\
\hline & SUMOylation & SUMO1 & Lys81, Lys89, Lys183 & Damage recognition & {$[67,68]$} \\
\hline & SUMOylation & - & Lys655 & Degradation & [69] \\
\hline & Dephosphorylation & WIP1 & Ser892 & Inactivation & [78] \\
\hline \multirow[t]{2}{*}{ XPD } & ISGylation & HERC5 & - & Not investigated & [81] \\
\hline & Ubiquitination & - & Lys 701 & Possible ubiquitination site & [82] \\
\hline \multirow[t]{3}{*}{$\begin{array}{c}\mathrm{XPE} \\
\text { (DDB2) }\end{array}$} & Ubiquitination & CRL4(DDB2) & $\begin{array}{l}\text { Lys5, Lys11, Lys35, } \\
\text { Lys40, Lys151 }\end{array}$ & Autoubiquitination, Degradation & {$[54,60]$} \\
\hline & Deubiquitination & USP24 & - & Stabilization & [61] \\
\hline & PARylation & PARP1 & - & Stabilization & {$[83,84]$} \\
\hline \multirow[t]{2}{*}{ XPG } & Ubiquitination & CRL4(Cdt2) & & Degradation & [75] \\
\hline & Acetylation & p300/CBP & & Affinity for DNA lesions & [85] \\
\hline \multirow[t]{5}{*}{ CSB } & Ubiquitination & - & - & Degradation & [70] \\
\hline & Deubiquitination & USP7 & - & Stabilization & {$[72]$} \\
\hline & SUMOylation & $\mathrm{SUMO} 2 / 3$ & Lys205 & Efficient TC-NER & [73] \\
\hline & Phosphorylation & $\mathrm{c}-\mathrm{Abl}$ & Tyr932 & Nuclear localization & {$[86]$} \\
\hline & PARylation & PARP1 & - & Repair for oxidative DNA damage & [87] \\
\hline ERCC1 & Deubiquitination & USP45 & - & Access to damage site & [74] \\
\hline
\end{tabular}

\subsection{Phosphorylation, Acetylation, and PARylation}

The DNA damage response involves the coordination of multiple cellular responses including DNA repair, cell cycle checkpoint control, DNA replication, and apoptosis [88]. The ATR protein kinase, which is the major regulator of the DNA damage response, phosphorylates proteins associated with cell cycle checkpoints and DNA repair. ATR phosphorylates XPA at serine 196, which is located in the DNA-binding domain [76]. A phospho-deficient XPA mutant (S196A) exhibits greater UV sensitivity compared with the wildtype, while the phospho-mimic form (S196D) shows tolerance to UV damage. In addition, the downregulation of ATR in the presence of UV damage results in the destabilization of XPA, and S196A expressed in XPA cells compromises NER activity [77]. UV-induced phosphorylation of XPA by ATR stimulates NER by inhibiting HERC2-mediated ubiquitination, which promotes XPA stabilization and chromatin retention [77]. ATR also regulates nuclear translocation of XPA through interaction with importin- $\alpha 4$ [89]. The binding of importin- $\alpha 4$ to XPA is dependent on UV-irradiation. 
Knockdown of ATR reduces the amount of XPA interacting with importin- $\alpha 4$. Nuclear-Dbf2-related kinase 1 (NDR1) is a novel XPA-interacting protein that indirectly modulates NER activity via the ATR pathway [90]. The NDR1-depleted cells display reduced activity of ATR during UV-induced DNA damage, hypothesizing that NDR1 functions as a transducer of DNA damage signals to ATR. Wild-type p53-induced phosphatase 1 (WIP1) dephosphorylates XPA; thus overexpression of WIP1 decreases NER activity [78]. WIP1-deficient mice show accelerated repair kinetics on the UV lesions and less apoptosis than their wild-type counterparts. In vitro phosphatase assays have identified XPA and XPC as two potential WIP1 targets, thus WIP1 may repress NER activity by dephosphorylating and inactivating XPA and XPC after repair.

E2F1 has recently been identified as a novel NER-regulating factor that accumulates at sites of UV-induced DNA damage [91]. ATR phosphorylates E2F1 at serine 31, which increases E2F1 protein stability and its recruitment to sites of damage [92]. E2F1 then recruits GCN5 acetyltransferase, which mediates histone acetylation required for efficient NER [93]. Phosphorylation sites of CSB have been explored using a proteomic analysis. Among multiple putative phosphorylation sites, serine 1461 has been found as a critical target for ATM and ATR-mediated phosphorylation, since this is inducible in response to ionizing radiation [94,95]. In addition, tyrosine 932 has been defined to be phosphorylated by the Abelson murine leukemia viral oncogene homolog 1 (c-Abl) kinase. Oxidative DNA damage such as hydrogen peroxide induces CSB phosphorylation at tyrosine 932 by c-Abl, thereby regulating the subcellular localization of CSB to facilitate repair activity [86]. The XPB subunit of TFIIH is phosphorylated at serine 751 of XPB in vivo [80]. XPB phosphorylation does not alter TFIIH helicase activity but inhibits $5^{\prime}$ incision induced by XPF-ERCC1, which is regarded as a critical point for fine-tuning the NER activity. Expression of a phosphomimetic XPB-S751E mutant is unable to compensate the NER defect of XP-B cells, whereas XPB-S751 dephosphorylation or expression of a phospho-deficient mutant (S751A) can restore NER activity.

It has been reported that NER activity can be decreased by XPA acetylation and increased by XPA deacetylation [79]. Deacetylation of XPA is required for its interaction with replication protein RPA32 [79]. A recent report demonstrated that a non-lethal dose of UV radiation induces SIRT1 expression, which promotes the binding of XPA to the damaged DNA, consequently fostering NER activity following lethal dose of cisplatin treatment, hence explaining chemoresistance mechanism of SIRT1-overexpressing cancer cells [96]. Ras association domain-containing protein 1 (RASSF1A) modulates XPA acetylation in a SIRT1-dependent manner [97]. In the presence of SIRT1 inhibitor, RASSF1A is no longer able to promote XPA deacetylation. XPG is acetylated by p300 acetyltransferase and its homolog CREB-binding protein (CBP) in vivo, which facilitates XPG accumulation at sites of DNA damage in a PCNA-p21 dependent manner $[85,98]$. Knockdown of both p300/CBP by RNAi or by chemical inhibition with curcumin significantly reduces XPG acetylation, and a concomitant accumulation of the protein at DNA damage sites is observed. The ability of p21 to bind PCNA is found to regulate the interaction between p300 and XPG [99]. In addition, AKT-mediated p300 phosphorylation at serine 1834 increases histone acetylation, which allows NER factors access to the damaged DNA [100].

Poly(ADP-ribose) polymerases (PARPs) catalyze adenosine diphosphate (ADP)-ribosylation using nicotinamide adenine dinucleotide as a substrate, transferring ADP-ribose to an acceptor protein [101]. Inhibiting PARP enzymatic activity is an effective strategy to target cancer and decrease chemotherapy toxicity due to compromised DNA repair $[102,103]$. DNA damage induces PARP1 activity, which is required for UV-induced DNA repair [104]. Results of an in vitro PARP assay show that DDB2 is a target for PARP1-mediated PARylation, which promotes interaction between PARP1 and XPC and increases localization of XPC to DNA lesions [84]. PARP1-mediated PARylation stabilizes DDB2 by inhibiting its ubiquitination and regulates the recruitment of the chromatin remodeling enzyme amplified in liver cancer protein 1 (ALC1) [83]. XPA has a high binding affinity for PAR chains, and the PAR-binding motif overlaps the DDB and TFIIF interaction domains of XPA [105,106]. PARP1 regulates the association of XPA to damaged chromatin, and XPA in turn stimulates PARP1 enzymatic 
activity [107]. In addition, PARP1 can PARylate both N- and C-terminals of CSB after oxidative DNA damage, which inhibits the ATP hydrolysis activity of CSB [87]. It will be intriguing to investigate how PARylation affects the interplay of the NER factors at DNA damage sites and to determine whether PARylation is a critical regulatory factor for coordinating the repair mechanisms.

\section{Concluding Remark}

Recent studies show that hotspot somatic mutations in cancer genomes include active gene promoters where the binding of transcription factors impairs NER activity $[108,109]$. These findings emphasize the critical importance of NER in maintaining genome stability. Understanding the transcriptional and posttranslational regulation of NER factors may enable the manipulation of NER activity to protect skin from UV-mediated damage and enhance the efficacy of chemotherapeutic agents. For cancer patients, pharmacological inhibition of NER is expected to improve chemosensitivity but nontoxic NER inhibitors are rare. This highly important issue needs more intense exploration.

Acknowledgments: This study was supported by a grant from the National R\&D Program for Cancer Control, Ministry of Health \& Welfare, Republic of Korea (1420070) and National Research Foundation of Republic of Korea (NRF-2015R1D1A1A01056994), and Brain Busan 21 Project.

Author Contributions: Jeong-Min Park and Tae-Hong Kang conceived and designed the study; Jeong-Min Park and Tae-Hong Kang analyzed the data; Jeong-Min Park and Tae-Hong Kang wrote the paper.

Conflicts of Interest: The authors declare no conflict of interest.

\section{Abbreviations}

$\begin{array}{ll}\text { 6-4PP } & \text { Pyrimidine-pyrimidone (6-4) photoproduct } \\ \text { ADP } & \text { Adenosine diphosphate } \\ \text { ALC1 } & \text { Amplified in liver cancer protein 1 } \\ \text { AP-1 } & \text { Activator protein 1 (also known as c-Jun) } \\ \text { ARF } & \text { Alternative reading frame } \\ \text { ATR } & \text { Ataxia-telangiectasia mutated and RAD3-related protein kinase } \\ \text { BRCA1 } & \text { Breast cancer 1 } \\ \text { c-Abl } & \text { Abelson murine leukemia viral oncogene homolog 1 } \\ \text { c-Fos } & \text { Proto-oncogene c-Fos } \\ \text { CBP } & \text { CREB-binding protein } \\ \text { CEBPG } & \text { CCAAT/enhancer-binding protein gamma } \\ \text { COP9 } & \text { Constitutive photomorphogenesis 9 } \\ \text { CPD } & \text { Cyclobutane pyrimidine dimer } \\ \text { CRL4 } & \text { Cullin 4A (CUL4A)-regulator of cullins 1 (ROC1) E3 ubiquitin ligase } \\ \text { Cry1 } & \text { Cryptochrome 1 } \\ \text { CSB } & \text { Cockayne syndrome protein B } \\ \text { CUL4A } & \text { Cullin 4A } \\ \text { DDB1 } & \text { DNA damage binding protein 1 } \\ \text { ERCC1 } & \text { Excision repair cross-complementation group 1 } \\ \text { GG-NER } & \text { Global genome repair } \\ \text { Gli1 } & \text { Glioma-associated oncogene homolog 1 } \\ \text { HBx } & \text { Hepatitis B virus x protein } \\ \text { HECT } & \text { Homologous to the E6-AP carboxyl terminus } \\ \text { HERC2 } & \text { HECT domain and RCC1-like domain-containing protein 2 } \\ \text { hHR23B } & \text { Human UV excision repair protein RAD23 homolog B } \\ \text { HIF-1 } \alpha & \text { Hypoxia-inducible factor-1 } \alpha \\ \text { HMGA1 } & \text { High-mobility group A 1 } \\ \text { HRE } & \text { Hypoxia response element } \\ \text { ISGylation } & \text { Protein conjugation by interferon-stimulated gene 15 } \\ \text { MAPK } & \text { Mitogen-activated protein kinase } \\ \text { MC1R } & \text { Melanocortin 1 receptor } \\ \text { NAD } & \text { Nicotinamide adenine dinucleotide } \\ \text { NDR1 } & \text { Nuclear-Dbf2-related family of Ser/Thr kinases 1 } \\ \text { NEDD8 } & \text { Neural precursor cell expressed developmentally down-regulated protein 8 } \\ \text { NER } & \text { Nucleotide excision repair } \\ \text { PARP } & \text { Poly(ADP ribose) polymerases } \\ \text { PARylation } & \text { Poly(ADP-ribosyl)ation } \\ \text { RASSF1A } & \text { Ras association domain-containing protein 1 } \\ & \end{array}$




\begin{tabular}{|c|c|}
\hline RLD & RCC1 like domain \\
\hline RNAPII & RNA polymerase II \\
\hline RNF111 & RING finger protein 111 \\
\hline ROC1 & Regulator of cullins 1 \\
\hline SIRT1 & Sirtuin 1 \\
\hline Sp1 & Specificity protein 1 \\
\hline SUMO & Small ubiquitin-related modifier \\
\hline TAp $63 \gamma$ & Transactivation isoforms of $\mathrm{p} 63 \gamma$ \\
\hline TC-NER & Transcription-coupled repair \\
\hline TGF- $\beta$ & Transforming growth factor- $\beta$ \\
\hline UBD & Ubiquitin-binding domain \\
\hline USP & Ubiquitin-specific processing protease \\
\hline UV & Ultraviolet \\
\hline UVRAG & UV radiation resistance-associated gene protein \\
\hline UVSSA & UV-sensitive syndrome A \\
\hline WIP1 & Wild-type p53-induced phosphatase 1 \\
\hline XPA & Xeroderma pigmentosum complementation group A \\
\hline XPB & Xeroderma pigmentosum complementation group B (also known as ERCC3) \\
\hline XPC & Xeroderma pigmentosum complementation group $\mathrm{C}$ \\
\hline XPD & Xeroderma pigmentosum complementation group D (also known as ERCC2) \\
\hline $\mathrm{XPE}$ & Xeroderma pigmentosum complementation group E (also known as DDB2) \\
\hline XPF & Xeroderma pigmentosum complementation group $\mathrm{F}$ (also known as ERCC4) \\
\hline XPG & Xeroderma pigmentosum complementation group G (also known as ERCC5) \\
\hline YY1 & Yin Yang 1 \\
\hline
\end{tabular}

\section{References}

1. D'Orazio, J.; Jarrett, S.; Amaro-Ortiz, A.; Scott, T. UV radiation and the skin. Int. J. Mol. Sci. 2013, 14, 12222-12248. [CrossRef] [PubMed]

2. Seebode, C.; Lehmann, J.; Emmert, S. Photocarcinogenesis and skin cancer prevention strategies. Anticancer Res. 2016, 36, 1371-1378. [PubMed]

3. Hofbauer, G. Phototherapy and carcinogenesis. Hautarzt 2013, 64, 349-353. [CrossRef] [PubMed]

4. Mitchell, D.L.; Karentz, D. The Induction and Repair of DNA Photodamage in the Environment. In Environmental UV Photobiology; Young, A.R., Moan, J., Björn, L.O., Nultsch, W., Eds.; Springer: Boston, MA, USA, 1993; pp. 345-377.

5. Latonen, L.; Laiho, M. Cellular UV damage responses-Functions of tumor suppressor p53. Biochim. Biophys. Acta-Rev. Cancer 2005, 1755, 71-89. [CrossRef] [PubMed]

6. Daya-Grosjean, L.; Dumaz, N.; Sarasin, A. The specificity of p53 mutation spectra in sunlight induced human cancers. J. Photochem. Photobiol. B 1995, 28, 115-124. [CrossRef]

7. Brash, D.E. UV signature mutations. Photochem. Photobiol. 2015, 91, 15-26. [CrossRef] [PubMed]

8. Vrouwe, M.G.; Pines, A.; Overmeer, R.M.; Hanada, K.; Mullenders, L.H.F. UV-induced photolesions elicit ATR-kinase-dependent signaling in non-cycling cells through nucleotide excision repair-dependent and -independent pathways. J. Cell Sci. 2011, 124, 435-446. [CrossRef] [PubMed]

9. Scharer, O.D. Nucleotide excision repair in eukaryotes. Cold Spring Harb. Perspect. Biol. 2013, 5, a012609. [CrossRef] [PubMed]

10. Marteijn, J.A.; Lans, H.; Vermeulen, W.; Hoeijmakers, J.H.J. Understanding nucleotide excision repair and its roles in cancer and ageing. Nat. Rev. Mol. Cell Biol. 2014, 15, 465-481. [CrossRef] [PubMed]

11. Hanawalt, P.C.; Spivak, G. Transcription-coupled DNA repair: Two decades of progress and surprises. Nat. Rev. Mol. Cell Biol. 2008, 9, 958-970. [CrossRef] [PubMed]

12. Cleaver, J.E.; Lam, E.T.; Revet, I. Disorders of nucleotide excision repair: The genetic and molecular basis of heterogeneity. Nat. Rev. Genet. 2009, 10, 756-768. [CrossRef] [PubMed]

13. De Boer, J.; Hoeijmakers, J.H.J. Nucleotide excision repair and human syndromes. Carcinogenesis 2000, 21, 453-460. [CrossRef] [PubMed] 
14. Batty, D.P.; Wood, R.D. Damage recognition in nucleotide excision repair of DNA. Gene 2000, 241, $193-204$. [CrossRef]

15. Kang, T.H.; Reardon, J.T.; Kemp, M.; Sancar, A. Circadian oscillation of nucleotide excision repair in mammalian brain. Proc. Natl. Acad. Sci. USA 2009, 106, 2864-2867. [CrossRef] [PubMed]

16. Kang, T.H.; Lindsey-Boltz, L.A.; Reardon, J.T.; Sancar, A. Circadian control of XPA and excision repair of cisplatin-DNA damage by cryptochrome and HERC2 ubiquitin ligase. Proc. Natl. Acad. Sci. USA 2010, 107, 4890-4895. [CrossRef] [PubMed]

17. Adair, J.E.; Maloney, S.C.; Dement, G.A.; Wertzler, K.J.; Smerdon, M.J.; Reeves, R. High-mobility group A1 proteins inhibit expression of nucleotide excision repair factor xeroderma pigmentosum group A. Cancer Res. 2007, 67, 6044-6052. [CrossRef] [PubMed]

18. Liu, Y.B.; Bernauer, A.M.; Yingling, C.M.; Belinsky, S.A. HIF1 $\alpha$ regulated expression of XPA contributes to cisplatin resistance in lung cancer. Carcinogenesis 2012, 33, 1187-1192. [CrossRef] [PubMed]

19. Ma, L.; Weeda, G.; Jochemsen, A.G.; Bootsma, D.; Hoeijmakers, J.H.J.; van der Eb, A.J. Molecular and functional analysis of the XPBC/ERCC-3 promoter: Transcription activity is dependent on the integrity of an Sp1-binding site. Nucleic Acids Res. 1992, 20, 217-224. [CrossRef] [PubMed]

20. Jaitovich-Groisman, I.; Benlimame, N.; Slagle, B.L.; Perez, M.H.; Alpert, L.; Song, D.J.; Fotouhi-Ardakani, N.; Galipeau, J.; Alaoui-Jamali, M.A. Transcriptional regulation of the TFIIH transcription repair components $\mathrm{XPB}$ and XPD by the hepatitis B virus $x$ protein in liver cells and transgenic liver tissue. J. Biol. Chem. 2001, 276, 14124-14132. [PubMed]

21. Adimoolam, S.; Ford, J.M. p53 and DNA damage-inducible expression of the xeroderma pigmentosum group C gene. Proc. Natl. Acad. Sci. USA 2002, 99, 12985-12990. [CrossRef] [PubMed]

22. Barckhausen, C.; Roos, W.P.; Naumann, S.C.; Kaina, B. Malignant melanoma cells acquire resistance to DNA interstrand cross-linking chemotherapeutics by p53-triggered upregulation of DDB2/XPC-mediated DNA repair. Oncogene 2014, 33, 1964-1974. [CrossRef] [PubMed]

23. Liu, J.; Lin, M.H.; Zhang, C.; Wang, D.D.; Feng, Z.H.; Hu, W.W. TAp63 $\gamma$ enhances nucleotide excision repair through transcriptional regulation of DNA repair genes. DNA Repair 2012, 11, 167-176. [CrossRef] [PubMed]

24. Hartman, A.R.; Ford, J.M. BRCA1 induces DNA damage recognition factors and enhances nucleotide excision repair. Nat. Genet. 2002, 32, 180-184. [CrossRef] [PubMed]

25. Piao, M.J.; Hewage, S.; Han, X.; Kang, K.A.; Kang, H.K.; Lee, N.H.; Hyun, J.W. Protective effect of diphlorethohydroxycarmalol against ultraviolet B radiation-Induced DNA damage by inducing the nucleotide excision repair system in HaCaT human keratinocytes. Mar. Drugs 2015, 13, 5629-5641. [CrossRef] [PubMed]

26. Rezvani, H.R.; Mahfouf, W.; Ali, N.; Chemin, C.; Ged, C.; Kim, A.L.; de Verneuil, H.; Taieb, A.; Bickers, D.R.; Mazurier, F. Hypoxia-inducible factor- $1 \alpha$ regulates the expression of nucleotide excision repair proteins in keratinocytes. Nucleic Acids Res. 2010, 38, 797-809. [CrossRef] [PubMed]

27. Ming, M.; Shea, C.R.; Guo, X.M.; Li, X.L.; Soltani, K.; Han, W.N.; He, Y.Y. Regulation of global genome nucleotide excision repair by SIRT1 through xeroderma pigmentosum C. Proc. Natl. Acad. Sci. USA 2010, 107, 22623-22628. [CrossRef] [PubMed]

28. Dominguez-Brauer, C.; Chen, Y.J.; Brauer, P.M.; Pimkina, J.; Raychaudhuri, P. ARF stimulates XPC to trigger nucleotide excision repair by regulating the repressor complex of E2F4. EMBO Rep. 2009, 10, 1036-1042. [CrossRef] [PubMed]

29. Qiang, L.; Shah, P.; Barcellos-Hoff, M.H.; He, Y.Y. TGF- $\beta$ signaling links E-cadherin loss to suppression of nucleotide excision repair. Oncogene 2016, 35, 3293-3302. [CrossRef] [PubMed]

30. Swope, V.; Alexander, C.; Starner, R.; Schwemberger, S.; Babcock, G.; Abdel-Malek, Z.A. Significance of the melanocortin 1 receptor in the DNA damage response of human melanocytes to ultraviolet radiation. Pigment Cell Melanoma Res. 2014, 27, 601-610. [CrossRef] [PubMed]

31. Merkel, P.; Khoury, N.; Bertolotto, C.; Perfetti, R. Insulin and glucose regulate the expression of the DNA repair enzyme XPD. Mol. Cell. Endocrinol. 2003, 201, 75-85. [CrossRef]

32. Tan, T.; Chu, G. p53 binds and activates the xeroderma pigmentosum DDB2 gene in humans but not mice. Mol. Cell. Biol. 2002, 22, 3247-3254. [CrossRef] [PubMed]

33. Christmann, M.; Tomicic, M.T.; Origer, J.; Aasland, D.; Kaina, B. c-Fos is required for excision repair of UV-light induced DNA lesions by triggering the re-synthesis of XPF. Nucleic Acids Res. 2006, 34, 6530-6539. [CrossRef] [PubMed] 
34. Tomicic, M.T.; Reischmann, P.; Rasenberger, B.; Meise, R.; Kaina, B.; Christmann, M. Delayed c-Fos activation in human cells triggers XPF induction and an adaptive response to UVC-induced DNA damage and cytotoxicity. Cell. Mol. Life Sci. 2011, 68, 1785-1798. [CrossRef] [PubMed]

35. Crawford, E.L.; Blomquist, T.; Mullins, D.N.; Yoon, Y.; Hernandez, D.R.; Al-Bagdhadi, M.; Ruiz, J.; Hammersley, J.; Willey, J.C. CEBPG regulates ERCC5/XPG expression in human bronchial epithelial cells and this regulation is modified by E2F1/YY1 interactions. Carcinogenesis 2007, 28, 2552-2559. [CrossRef] [PubMed]

36. Kang, T.H.; Reardon, J.T.; Sancar, A. Regulation of nucleotide excision repair activity by transcriptional and post-transcriptional control of the XPA protein. Nucleic Acids Res. 2011, 39, 3176-3187. [CrossRef] [PubMed]

37. Camenisch, U.; Dip, R.; Schumacher, S.B.; Schuler, B.; Naegeli, H. Recognition of helical kinks by xeroderma pigmentosum group A protein triggers DNA excision repair. Nat. Struct. Mol. Biol. 2006, 13, 278-284. [CrossRef] [PubMed]

38. Orelli, B.; McClendon, T.B.; Tsodikov, O.V.; Ellenberger, T.; Niedernhofer, L.J.; Scharer, O.D. The XPA-binding domain of ERCC1 is required for nucleotide excision repair but not other DNA repair pathways. J. Biol. Chem. 2010, 285, 3705-3712. [CrossRef] [PubMed]

39. Kang, T.H.; Sancar, A. Circadian regulation of DNA excision repair implications for chrono-chemotherapy. Cell Cycle 2009, 8, 1665-1667. [CrossRef] [PubMed]

40. Reeves, R. High mobility group (HMG) proteins: Modulators of chromatin structure and DNA repair in mammalian cells. DNA Repair 2015, 36, 122-136. [CrossRef] [PubMed]

41. Compe, E.; Egly, J.M. TFIIH: When transcription met DNA repair. Nat. Rev. Mol. Cell Biol. 2012, 13, 343-354. [CrossRef] [PubMed]

42. Kaczynski, J.; Cook, T.; Urrutia, R. Sp1- and Kruppel-like transcription factors. Genome Biol. 2003, 4, 206. [CrossRef] [PubMed]

43. Lee, Y.I.; Lee, S.; Lee, Y.; Bong, Y.S.; Hyun, S.W.; Yoo, Y.D.; Kim, S.J.; Kim, Y.W.; Poo, H.R. The human hepatitis $B$ virus transactivator $X$ gene product regulates $\mathrm{Sp} 1$ mediated transcription of an insulin-like growth factor II promoter 4. Oncogene 1998, 16, 2367-2380. [CrossRef] [PubMed]

44. Sugasawa, K.; Okamoto, T.; Shimizu, Y.; Masutani, C.; Iwai, S.; Hanaoka, F. A multistep damage recognition mechanism for global genomic nucleotide excision repair. Genes Dev. 2001, 15, 507-521. [CrossRef] [PubMed]

45. Min, J.H.; Pavletich, N.P. Recognition of DNA damage by the Rad4 nucleotide excision repair protein. Nature 2007, 449, 570-575. [CrossRef] [PubMed]

46. Wakasugi, M.; Kawashima, A.; Morioka, H.; Linn, S.; Sancar, A.; Mori, T.; Nikaido, O.; Matsunaga, T. DDB accumulates at DNA damage sites immediately after UV irradiation and directly stimulates nucleotide excision repair. J. Biol. Chem. 2002, 277, 1637-1640. [CrossRef] [PubMed]

47. Dotsch, V.; Bernassola, F.; Coutandin, D.; Candi, E.; Melino, G. p63 and p73, the ancestors of p53. Cold Spring Harb. Perspect. Biol. 2010, 2, a004887. [CrossRef] [PubMed]

48. Fagbemi, A.F.; Orelli, B.; Scharer, O.D. Regulation of endonuclease activity in human nucleotide excision repair. DNA Repair 2011, 10, 722-729. [CrossRef] [PubMed]

49. Christmann, M.; Kaina, B. Transcriptional regulation of human DNA repair genes following genotoxic stress: Trigger mechanisms, inducible responses and genotoxic adaptation. Nucleic Acids Res. 2013, 41, 8403-8420. [CrossRef] [PubMed]

50. Youn, C.K.; Kim, M.H.; Cho, H.J.; Kim, H.B.; Chang, I.Y.; Chung, M.H.; You, H.J. Oncogenic H-Ras up-regulates expression of ERCC1 to protect cells from platinum-based anticancer agents. Cancer Res. 2004, 64, 4849-4857. [CrossRef] [PubMed]

51. Kudo, K.; Gavin, E.; Das, S.; Amable, L.; Shevde, L.A.; Reed, E. Inhibition of Gli1 results in altered c-Jun activation, inhibition of cisplatin-induced upregulation of ERCC1, XPD and XRCC1, and inhibition of platinum-DNA adduct repair. Oncogene 2012, 31, 4718-4724. [CrossRef] [PubMed]

52. Bergink, S.; Jentsch, S. Principles of ubiquitin and SUMO modifications in DNA repair. Nature 2009, 458, 461-467. [CrossRef] [PubMed]

53. Sugasawa, K.; Okuda, Y.; Saijo, M.; Nishi, R.; Matsuda, N.; Chu, G.; Mori, T.; Iwai, S.; Tanaka, K.; Tanaka, K.; et al. UV-induced ubiquitylation of XPC protein mediated by UV-DDB-ubiquitin ligase complex. Cell 2005, 121, 387-400. [CrossRef] [PubMed] 
54. Fischer, E.S.; Scrima, A.; Bohm, K.; Matsumoto, S.; Lingaraju, G.M.; Faty, M.; Yasuda, T.; Cavadini, S.; Wakasugi, M.; Hanaoka, F.; et al. The molecular basis of CRL4DDB2/CSA ubiquitin ligase architecture, targeting, and activation. Cell 2011, 147, 1024-1039. [CrossRef] [PubMed]

55. Hannah, J.; Zhou, P.B. Regulation of DNA damage response pathways by the cullin-RING ubiquitin ligases. DNA Repair 2009, 8, 536-543. [CrossRef] [PubMed]

56. Scrima, A.; Konickova, R.; Czyzewski, B.K.; Kawasaki, Y.; Jeffrey, P.D.; Groisman, R.; Nakatani, Y.; Iwai, S.; Pavletich, N.P.; Thoma, N.H. Structural basis of UV DNA-damage recognition by the DDB1-DDB2 complex. Cell 2008, 135, 1213-1223. [CrossRef] [PubMed]

57. Guerrero-Santoro, J.; Kapetanaki, M.G.; Hsieh, C.L.; Gorbachinsky, I.; Levine, A.S.; Rapic-Otrin, V. The cullin 4B-based UV-damaged DNA-binding protein ligase binds to UV-damaged chromatin and ubiquitinates histone H2A. Cancer Res. 2008, 68, 5014-5022. [CrossRef] [PubMed]

58. Wang, H.; Zhai, L.; Xu, J.; Joo, H.Y.; Jackson, S.; Erdjument-Bromage, H.; Tempst, P.; Xiong, Y.; Zhang, Y. Histone $\mathrm{H} 3$ and $\mathrm{H} 4$ ubiquitylation by the CUL4-DDB-ROC1 ubiquitin ligase facilitates cellular response to DNA damage. Mol. Cell 2006, 22, 383-394. [CrossRef] [PubMed]

59. Takedachi, A.; Saijo, M.; Tanaka, K. DDB2 complex-mediated ubiquitylation around DNA damage is oppositely regulated by XPC and $\mathrm{Ku}$ and contributes to the recruitment of XPA. Mol. Cell. Biol. 2010, 30, 2708-2723. [CrossRef] [PubMed]

60. Nag, A.; Bondar, T.; Shiv, S.; Raychaudhuri, P. The xeroderma pigmentosum group E gene product DDB2 is a specific target of cullin 4A in mammalian cells. Mol. Cell. Biol. 2001, 21, 6738-6747. [CrossRef] [PubMed]

61. Zhang, L.; Lubin, A.; Chen, H.; Sun, Z.; Gong, F. The deubiquitinating protein USP24 interacts with DDB2 and regulates DDB2 stability. Cell Cycle 2012, 11, 4378-4384. [CrossRef] [PubMed]

62. Puumalainen, M.R.; Ruthemann, P.; Min, J.H.; Naegeli, H. Xeroderma pigmentosum group C sensor: Unprecedented recognition strategy and tight spatiotemporal regulation. Cell. Mol. Life Sci. 2016, 73, 547-566. [CrossRef] [PubMed]

63. Zhao, Q.; Barakat, B.M.; Qin, S.; Ray, A.; El-Mahdy, M.A.; Wani, G.; Arafa, E.S.; Mir, S.N.; Wang, Q.E.; Wani, A.A. The p38 mitogen-activated protein kinase augments nucleotide excision repair by mediating DDB2 degradation and chromatin relaxation. J. Biol. Chem. 2008, 283, 32553-32561. [CrossRef] [PubMed]

64. Yang, Y.F.; He, S.S.; Wang, Q.X.; Li, F.; Kwak, M.J.; Chen, S.; O'Connell, D.; Zhang, T.; Pirooz, S.D.; Jeon, Y.; et al. Autophagic UVRAG promotes UV-induced photolesion repair by activation of the CRL4(DDB2) E3 ligase. Mol. Cell 2016, 62, 507-519. [CrossRef] [PubMed]

65. Van Cuijk, L.; van Belle, G.J.; Turkyilmaz, Y.; Poulsen, S.L.; Janssens, R.C.; Theil, A.F.; Sabatella, M.; Lans, H.; Mailand, N.; Houtsmuller, A.B.; et al. SUMO and ubiquitin-dependent XPC exchange drives nucleotide excision repair. Nat. Commun. 2015, 6, 7499. [CrossRef] [PubMed]

66. Poulsen, S.L.; Hansen, R.K.; Wagner, S.A.; van Cuijk, L.; van Belle, G.J.; Streicher, W.; Wikstrom, M.; Choudhary, C.; Houtsmuller, A.B.; Marteijn, J.A.; et al. RNF111/Arkadia is a SUMO-targeted ubiquitin ligase that facilitates the DNA damage response. J. Cell Biol. 2013, 201, 797-807. [CrossRef] [PubMed]

67. Wang, Q.E.; Zhu, Q.Z.; Wani, G.; El-Mahdy, M.A.; Li, J.Y.; Wani, A.A. DNA repair factor XPC is modified by SUMO-1 and ubiquitin following UV irradiation. Nucleic Acids Res. 2005, 33, 4023-4034. [CrossRef] [PubMed]

68. Akita, M.; Tak, Y.S.; Shimura, T.; Matsumoto, S.; Okuda-Shimizu, Y.; Shimizu, Y.; Nishi, R.; Saitoh, H.; Iwai, S.; Mori, T.; et al. SUMOylation of xeroderma pigmentosum group C protein regulates DNA damage recognition during nucleotide excision repair. Sci. Rep. 2015, 5, 10984. [CrossRef] [PubMed]

69. Wang, Q.E.; Praetorius-Ibba, M.; Zhu, Q.; El-Mahdy, M.A.; Wani, G.; Zhao, Q.; Qin, S.; Patnaik, S.; Wani, A.A. Ubiquitylation-independent degradation of Xeroderma pigmentosum group $C$ protein is required for efficient nucleotide excision repair. Nucleic Acids Res. 2007, 35, 5338-5350. [CrossRef] [PubMed]

70. Groisman, R.; Kuraoka, I.; Chevallier, O.; Gaye, N.; Magnaldo, T.; Tanaka, K.; Kisselev, A.F.; Harel-Bellan, A.; Nakatani, Y. CSA-dependent degradation of CSB by the ubiquitin-proteasome pathway establishes a link between complementation factors of the Cockayne syndrome. Genes Dev. 2006, 20, 1429-1434. [CrossRef] [PubMed]

71. Anindya, R.; Mari, P.O.; Kristensen, U.; Kool, H.; Giglia-Mari, G.; Mullenders, L.H.; Fousteri, M.; Vermeulen, W.; Egly, J.M.; Svejstrup, J.Q. A ubiquitin-binding domain in cockayne syndrome B required for transcription-coupled nucleotide excision repair. Mol. Cell 2010, 38, 637-648. [CrossRef] [PubMed] 
72. Schwertman, P.; Lagarou, A.; Dekkers, D.H.; Raams, A.; van der Hoek, A.C.; Laffeber, C.; Hoeijmakers, J.H.; Demmers, J.A.; Fousteri, M.; Vermeulen, W.; et al. UV-sensitive syndrome protein UVSSA recruits USP7 to regulate transcription-coupled repair. Nat. Genet. 2012, 44, 598-602. [CrossRef] [PubMed]

73. Sin, Y.; Tanaka, K.; Saijo, M. The C-terminal region and SUMOylation of cockayne syndrome group B protein play critical roles in transcription-coupled nucleotide excision repair. J. Biol. Chem. 2016, 291, 1387-1397. [CrossRef] [PubMed]

74. Perez-Oliva, A.B.; Lachaud, C.; Szyniarowski, P.; Munoz, I.; Macartney, T.; Hickson, I.; Rouse, J.; Alessi, D.R. USP45 deubiquitylase controls ERCC1-XPF endonuclease-mediated DNA damage responses. EMBO J. 2015, 34, 326-343. [CrossRef] [PubMed]

75. Han, C.H.; Wani, G.; Zhao, R.; Qian, J.; Sharma, N.; He, J.S.; Zhu, Q.Z.; Wang, Q.E.; Wani, A.A. Cdt2-mediated XPG degradation promotes gap-filling DNA synthesis in nucleotide excision repair. Cell Cycle 2015, 14, 1103-1115. [CrossRef] [PubMed]

76. Shell, S.M.; Li, Z.K.; Shkriabai, N.; Kvaratskhelia, M.; Brosey, C.; Serrano, M.A.; Chazin, W.J.; Musich, P.R.; Zou, Y. Checkpoint kinase ATR promotes nucleotide excision repair of UV-induced DNA damage via physical interaction with xeroderma pigmentosum group A. J. Biol. Chem. 2009, 284, 24213-24222. [CrossRef] [PubMed]

77. Lee, T.H.; Park, J.M.; Leem, S.H.; Kang, T.H. Coordinated regulation of XPA stability by ATR and HERC2 during nucleotide excision repair. Oncogene 2014, 33, 19-25. [CrossRef] [PubMed]

78. Nguyen, T.A.; Slattery, S.D.; Moon, S.H.; Darlington, Y.F.; Lu, X.B.; Donehower, L.A. The oncogenic phosphatase WIP1 negatively regulates nucleotide excision repair. DNA Repair 2010, 9, 813-823. [CrossRef] [PubMed]

79. Fan, W.; Luo, J.Y. SIRT1 regulates UV-induced DNA repair through deacetylating XPA. Mol. Cell 2010, 39, 247-258. [CrossRef] [PubMed]

80. Coin, F.; Auriol, J.; Tapias, A.; Clivio, P.; Vermeulen, W.; Egly, J.M. Phosphorylation of XPB helicase regulates TFIIH nucleotide excision repair activity. EMBO J. 2004, 23, 4835-4846. [CrossRef] [PubMed]

81. Takeuchi, T.; Inoue, S.; Yokosawa, H. Identification and Herc5-mediated ISGylation of novel target proteins. Biochem. Biophys. Res. Commun. 2006, 348, 473-477. [CrossRef] [PubMed]

82. Kim, D.S.; Hahn, Y. Gains of ubiquitylation sites in highly conserved proteins in the human lineage. BMC Bioinform. 2012, 13, 306. [CrossRef] [PubMed]

83. Pines, A.; Vrouwe, M.G.; Marteijn, J.A.; Typas, D.; Luijsterburg, M.S.; Cansoy, M.; Hensbergen, P.; Deelder, A.; de Groot, A.; Matsumoto, S.; et al. PARP1 promotes nucleotide excision repair through DDB2 stabilization and recruitment of ALC1. J. Cell Biol. 2012, 199, 235-249. [CrossRef] [PubMed]

84. Robu, M.; Shah, R.G.; Petitclerc, N.; Brind'Amour, J.; Kandan-Kulangara, F.; Shah, G.M. Role of poly(ADP-ribose) polymerase-1 in the removal of UV-induced DNA lesions by nucleotide excision repair. Proc. Natl. Acad. Sci. USA 2013, 110, 1658-1663. [CrossRef] [PubMed]

85. Tillhon, M.; Cazzalini, O.; Nardo, T.; Necchi, D.; Sommatis, S.; Stivala, L.A.; Scovassi, A.I.; Prosperi, E. p300/CBP acetyl transferases interact with and acetylate the nucleotide excision repair factor XPG. DNA Repair 2012, 11, 844-852. [CrossRef] [PubMed]

86. Imam, S.Z.; Indig, F.E.; Cheng, W.H.; Saxena, S.P.; Stevnsner, T.; Kufe, D.; Bohr, V.A. Cockayne syndrome protein B interacts with and is phosphorylated by c-Abl tyrosine kinase. Nucleic Acids Res. 2007, 35, 4941-4951. [CrossRef] [PubMed]

87. Thorslund, T.; von Kobbe, C.; Harrigan, J.A.; Indig, F.E.; Christiansen, M.; Stevnsner, T.; Bohr, V.A. Cooperation of the Cockayne syndrome group B protein and poly(ADP-ribose) polymerase 1 in the response to oxidative stress. Mol. Cell. Biol. 2005, 25, 7625-7636. [CrossRef] [PubMed]

88. Cimprich, K.A.; Cortez, D. ATR: An essential regulator of genome integrity. Nat. Rev. Mol. Cell Biol. 2008, 9, 616-627. [CrossRef] [PubMed]

89. Li, Z.K.; Musich, P.R.; Cartwright, B.M.; Wang, H.; Zou, Y. UV-induced nuclear import of XPA is mediated by importin- $\alpha 4$ in an ATR-dependent manner. PLoS ONE 2013, 8, e68297. [CrossRef] [PubMed]

90. Park, J.M.; Choi, J.Y.; Yi, J.M.; Chung, J.W.; Leem, S.H.; Koh, S.S.; Kang, T.H. NDR1 modulates the UV-induced DNA-damage checkpoint and nucleotide excision repair. Biochem. Biophys. Res. Commun. 2015, 461, 543-548. [CrossRef] [PubMed] 
91. Guo, R.F.; Chen, J.; Zhu, F.; Biswas, A.K.; Berton, T.R.; Mitchell, D.L.; Johnson, D.G. E2F1 localizes to sites of UV-induced DNA damage to enhance nucleotide excision repair. J. Biol. Chem. 2010, 285, 19308-19315. [CrossRef] [PubMed]

92. Biswas, A.K.; Mitchell, D.L.; Johnson, D.G. E2F1 responds to ultraviolet radiation by directly stimulating DNA repair and suppressing carcinogenesis. Cancer Res. 2014, 74, 3369-3377. [CrossRef] [PubMed]

93. Guo, R.F.; Chen, J.; Mitchell, D.L.; Johnson, D.G. GCN5 and E2F1 stimulate nucleotide excision repair by promoting H3K9 acetylation at sites of damage. Nucleic Acids Res. 2011, 39, 1390-1397. [CrossRef] [PubMed]

94. Lake, R.J.; Fan, H.Y. Structure, function and regulation of CSB: A multi-talented gymnast. Mech. Ageing Dev. 2013, 134, 202-211. [CrossRef] [PubMed]

95. Matsuoka, S.; Ballif, B.A.; Smogorzewska, A.; McDonald, E.R.; Hurov, K.E.; Luo, J.; Bakalarski, C.E.; Zhao, Z.M.; Solimini, N.; Lerenthal, Y.; et al. ATM and ATR substrate analysis reveals extensive protein networks responsive to DNA damage. Science 2007, 316, 1160-1166. [CrossRef] [PubMed]

96. Choi, J.Y.; Park, J.M.; Yi, J.M.; Leem, S.H.; Kang, T.H. Enhanced nucleotide excision repair capacity in lung cancer cells by preconditioning with DNA-damaging agents. Oncotarget 2015, 6, 22575-22586. [CrossRef] [PubMed]

97. Donninger, H.; Clark, J.; Rinaldo, F.; Nelson, N.; Barnoud, T.; Schmidt, M.L.; Hobbing, K.R.; Vos, M.D.; Sils, B.; Clark, G.J. The RASSF1A tumor suppressor regulates XPA-mediated DNA repair. Mol. Cell. Biol. 2015, 35, 277-287. [CrossRef] [PubMed]

98. Feltes, B.C.; Bonatto, D. Overview of xeroderma pigmentosum proteins architecture, mutations and post-translational modifications. Mutat. Res. Rev. Mutat. Res. 2015, 763, 306-320. [CrossRef] [PubMed]

99. Wang, Q.E.; Han, C.H.; Zhao, R.; Wani, G.; Zhu, Q.Z.; Gong, L.; Battu, A.; Racoma, I.; Sharma, N.; Wani, A.A. p38 MAPK- and Akt-mediated p300 phosphorylation regulates its degradation to facilitate nucleotide excision repair. Nucleic Acids Res. 2013, 41, 1722-1733. [CrossRef] [PubMed]

100. Huang, W.C.; Chen, C.C. Akt-phosphorylation of p300 at Ser-1834 is essential for its histone acetyltransferase and transcriptional activity. Mol. Cell. Biol. 2005, 25, 6592-6602. [CrossRef] [PubMed]

101. Ame, J.C.; Spenlehauer, C.; de Murcia, G. The PARP superfamily. Bioessays 2004, 26, 882-893. [CrossRef] [PubMed]

102. Rouleau, M.; Patel, A.; Hendzel, M.J.; Kaufmann, S.H.; Poirier, G.G. PARP inhibition: PARP1 and beyond. Nat. Rev. Cancer 2010, 10, 293-301. [CrossRef] [PubMed]

103. Choi, J.Y.; Joh, H.M.; Park, J.M.; Kim, M.J.; Chung, T.H.; Kang, T.H. Non-thermal plasma-induced apoptosis is modulated by ATR-and PARP1-mediated DNA damage responses and circadian clock. Oncotarget 2016, 7, 32980-32989. [CrossRef] [PubMed]

104. Pines, A.; Mullenders, L.H.; van Attikum, H.; Luijsterburg, M.S. Touching base with PARPs: Moonlighting in the repair of UV lesions and double-strand breaks. Trends Biochem. Sci. 2013, 38, 321-330. [CrossRef] [PubMed]

105. Fahrer, J.; Kranaster, R.; Altmeyer, M.; Marx, A.; Burkle, A. Quantitative analysis of the binding affinity of poly(ADP-ribose) to specific binding proteins as a function of chain length. Nucleic Acids Res. 2007, 35, e143. [CrossRef] [PubMed]

106. Fischer, J.M.F.; Popp, O.; Gebhard, D.; Veith, S.; Fischbach, A.; Beneke, S.; Leitenstorfer, A.; Bergemann, J.; Scheffner, M.; Ferrando-May, E.; et al. Poly(ADP-ribose)-mediated interplay of XPA and PARP1 leads to reciprocal regulation of protein function. FEBS J. 2014, 281, 3625-3641. [CrossRef] [PubMed]

107. King, B.S.; Cooper, K.L.; Liu, K.J.; Hudson, L.G. Poly(ADP-ribose) contributes to an association between poly(ADP-ribose) polymerase-1 and xeroderma pigmentosum complementation group A in nucleotide excision repair. J. Biol. Chem. 2012, 287, 10. [CrossRef] [PubMed]

108. Perera, D.; Poulos, R.C.; Shah, A.; Beck, D.; Pimanda, J.E.; Wong, J.W.H. Differential DNA repair underlies mutation hotspots at active promoters in cancer genomes. Nature 2016, 532, 259-263. [CrossRef] [PubMed]

109. Sabarinathan, R.; Mularoni, L.; Deu-Pons, J.; Gonzalez-Perez, A.; Lopez-Bigas, N. Nucleotide excision repair is impaired by binding of transcription factors to DNA. Nature 2016, 532, 264-267. [CrossRef] [PubMed]

(C) 2016 by the authors; licensee MDPI, Basel, Switzerland. This article is an open access article distributed under the terms and conditions of the Creative Commons Attribution (CC-BY) license (http:/ / creativecommons.org/licenses/by/4.0/). 